\title{
Development of muffins with green pea flour and their physical and sensory evaluation and essential amino acid content
}

\author{
Daiane de Souza Gomes ${ }^{1}$ (i) Lucas Silva Rosa $^{2}$ (i) Layse do Prado Cordoba $^{1}$ (i) \\ Fernanda Fiorda-Mello ${ }^{3}$ (D) Michele Rigon Spier ${ }^{1}$ (i) Nina Waszczynskyj ${ }^{1}$ (i)
}

${ }^{1}$ Universidade Federal do Paraná, 81531-980, Curitiba, PR, Brasil. E-mail: daian_sg@yahoo.com.br. "Corresponding author.

${ }^{2}$ Universidade Estadual de Ponta Grossa (UEPG), Ponta Grossa, PR, Brasil.

${ }^{3}$ Universidade Federal do Pampa (UNIPAMPA), Bagé, RS, Brasil.

ABSTRACT: Wheat flour $(W F)$, pea flour $(P F)$ and whole wheat flour $(W W F)$ were mixed in different ratios by applying a simplex-centroid mixture design, in order to evaluate the impact of these combinations on the physical and sensorial properties of muffins. The interaction between WF and WWF produced muffins with brighter crusts and muffins prepared with higher ration of PF were harder. The ranking test was performed with the objective of identifying the most preferred muffin experiments according to the flavor attribute. The experiments with the lowest ranking scores were selected and submitted to the acceptance test. In the acceptance test, the attributes of color, taste, texture and overall acceptance were evaluated, where muffins obtained scores higher than 7 ("moderately liked"), indicating good acceptance of all experiments. The experiment (a) (80\% of WF, 10\% of PF and $10 \%$ of WWF) was chosen for presenting the highest set of scores.

Key words: bakery products, mixture design, texture, color analysis.

Desenvolvimento de muffins com farinha de ervilha verde: sua avaliação física, sensorial e teor de aminoácidos essenciais

RESUMO: A farinha de trigo especial (FT), farinha de ervilha (FE) efarinha de trigo integral (FTI) foram misturadas em diferentes proporções, mediante a aplicação de um delineamento de misturas simplex-centroide, com a finalidade de avaliar o impacto dessas combinações nas propriedades fisicas e sensoriais dos muffins. A interação entre FT e FTI produziu muffins com maior luminosidade na crosta e os muffins preparados com maior proporção de FE foram mais duros. O teste de ordenação foi realizado com objetivo de os julgadores ordenarem os experimentos de muffins mais preferidos de acordo com o atributo sabor. Os experimentos com as menores somas de ordem foram selecionados e submetidos ao teste de aceitação. No teste de aceitação foram avaliados os atributos de cor, sabor, textura e aparência global, em que os muffins obtiveram notas maiores que sete ("gostei moderadamente"), indicando uma boa aceitação de todos os experimentos. O experimento (a) $(80 \%$ de FT, $10 \%$ de FE e 10\% de FTI) foi escolhido por apresentar o maior conjunto de notas.

Palavras-chave: produtos de panificação, delineamento de misturas, textura, análise de cor.

\section{INTRODUCTION}

The cultivation of legume seeds has gained interest due to its nutritional profile. Among legumes, green pea (Pisum sativum L.) is one of the oldest and widely used food crops in the world. In 2018, global pea production reached 21.22 million tonnes (ZHOU et al., 2019; VATANSEVER et al., 2020; FAO, 2020). Peas are an excellent source of protein and dietary energy for humans and cattle. The content of carbohydrates, dietary fiber and proteins (on a dry basis) vary between 55$56 \%, 12-14 \%$ and $22-25 \%$, respectively (COLLAR et al, 2014; YILDIZ et al., 2021). The protein present in peas has high quality, as it is an important source of essential amino acids such as histidine, lysine, phenylalanine and threonine (MILLAR et al., 2019a). Recently, pea derivatives, such as flour, starch, protein isolate and pea fiber, appears as ingredientes of high added value in the composition of many food products (KEHLET et al., 2017; BECK et al., 2018; LU et al., 2018; PIETRASIK et al., 2020). The flour retains much of the nutritional properties of the raw pea and has functional characteristics that favor its use in foods such as pasta, bakery and confectionery, meat products and snacks (CARMO et al., 2019; REN et al., 2021).

In bread, the replacement of part of the wheat flour with pea flour significantly increased the protein content, providing a well-balanced amino acid

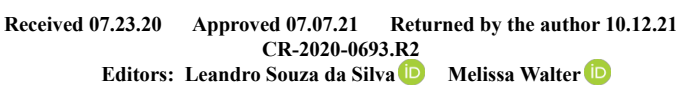


profile (MILLAR et al, 2019b). This procedure, in addition to diluting wheat protein, can provide consumers with healthy and easily digestible products. The use of pea flour in biscuits provided good functional and sensory properties (ZHAO et al., 2019).

Muffins are bakery products, popularly eaten during breakfast and afternoon snacks, with high consumer acceptance. The spongy texture of muffins is due to the porous structure and high volume, which are obtained through many small air bubbles incorporated in the dough. On the other hand, usually high in sugar and fat (SCIAMMARO et al., 2018; STRUCK et al., 2016). In this sense, the incorporation of ingredients with high nutritional value can enrich the product.

Studies have been carried out to investigate the interaction between flours on the nutritional, technological and sensory properties of the final product. To analyze the effects of flours and their interactions on the evaluated attributes, the mixture design methodology is used (SILVA et al., 2015; YILMAZ et al., 2015; IKEDA et al., 2018).

In this context, the aim of this study was to verify the effect of partial substitution of wheat flour in muffins formulation with pea and whole wheat flour, in order to evaluate the effect of these combinations on technological, sensorial characteristics and essential amino acids content of the final product.

\section{MATERIALS AND METHODS}

\section{Material and flour preparation}

Pea (Pisum sativum L.) Mikado variety (batch 11/06) samples were supplied by EMBRAPA, which is located in Brasília-FD. All samples were sent in 2015 and are from sun exposed crops. After being selected, the peas were sanitized with a sodium hypochlorite solution $(150 \mathrm{mg} / \mathrm{L})$ for $15 \mathrm{~min}$ and then washed in running water. Water and dried in an oven with air circulation $\left(40{ }^{\circ} \mathrm{C}\right.$ for $\left.24 \mathrm{~h}\right)$. After drying, the grains were ground in a knife mill until they approached the particle size of the wheat flour. Other raw materials were purchased at local commerce in the city of Curitiba - PR.

Experimental design, formulation and muffins preparation

Muffins were prepared using one basic formulation: $100 \mathrm{~g}$ flour, $80 \mathrm{~g}$ sugar, $80 \mathrm{~g}$ eggs, $65 \mathrm{~g}$ milk, $50 \mathrm{~g}$ butter and $5 \mathrm{~g}$ sodium bicarbonate. The proportions of the ingredients were based on JAUHARAH et al. (2014). Two-stage experiments were performed for the evaluation of partial substitution of wheat flour with whole wheat flour and pea flour. In step 1 , a preliminary test was carried out with the basic formulation of a muffin to establish the maximum level of substitution for pea flour and whole wheat flour. In step 2, a simplex centroid design with three components and 7 experiments (Table 1) was utilized to determine the effects of each type of flour (ternary mixtures) on the muffin's physical characteristics (BOX et al., 2005). A maximum limit of $30 \%$ and minimum of $10 \%$ for the whole wheat and pea flour was employed. Moreover, it was set for the wheat flour a maximum limit of $80 \%$ and minimum of $60 \%$. Two replicates were introduced in experiment 7 (experiments 8 and 9) to calculate the experimental error.

Table 1 - Experimental design of the mixtures of flours used to make the muffins.

\begin{tabular}{|c|c|c|c|c|c|c|}
\hline \multirow[t]{3}{*}{ Experiment } & \multicolumn{6}{|c|}{ 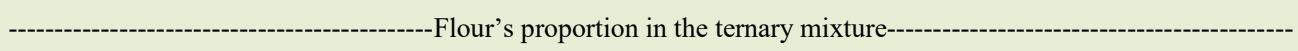 } \\
\hline & \multicolumn{3}{|c|}{ 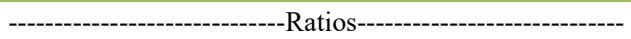 } & \multicolumn{3}{|c|}{ 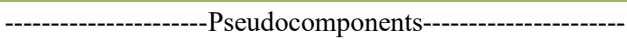 } \\
\hline & WF & PF & WWF & WF & PF & WWF \\
\hline (a) & 0.80 & 0.10 & 0.10 & 1 & 0 & 0 \\
\hline (b) & 0.60 & 0.30 & 0.10 & 0 & 1 & 0 \\
\hline (c) & 0.60 & 0.10 & 0.30 & 0 & 0 & 1 \\
\hline (d) & 0.70 & 0.20 & 0.10 & 0.5 & 0.5 & 0 \\
\hline (e) & 0.70 & 0.10 & 0.20 & 0.5 & 0 & 0.5 \\
\hline (f) & 0.60 & 0.20 & 0.20 & 0 & 0.5 & 0.5 \\
\hline$(\mathrm{g})$ & 0.66 & 0.17 & 0.17 & 0.33 & 0.33 & 0.33 \\
\hline (h) & 0.66 & 0.17 & 0.17 & 0.33 & 0.33 & 0.33 \\
\hline (i) & 0.66 & 0.17 & 0.17 & 0.33 & 0.33 & 0.33 \\
\hline
\end{tabular}

Note: WF: Wheat Flour; PF: Pea Flour; WWF: Whole Wheat Flour. $\mathrm{WF}+\mathrm{PF}+\mathrm{WWF}=1$ or $100 \%$ 
The preparation method was based on JAUHARAH et al. (2014), with some adaptations. Eggs were beaten with sugar and butter at $80 \%$ of maximum speed during 5 minutes in a planetary mixer (KitchenAid). Thereafter, flour (Table 1) and milk were added to obtain the dough, which was beaten for 3 minutes at $60 \%$ of maximum speed. Finally, the sodium bicarbonate was added and the dough was homogenized for 1 minute at $40 \%$ of maximum speed. Dough aliquots of $60 \mathrm{~g}$ were transferred to paper forms (4 $\mathrm{cm} \times 5 \mathrm{~cm}$ height /diameter), obtaining 6 muffins that were baked in Fisher electric oven for 25 minutes at $180^{\circ} \mathrm{C}$.

\section{Color analysis}

For the color analysis of muffins (crust and crumb), it was used the MiniScan XE 45/0-L Plus reflectance spectrophotometer (Hunter Inc), which consists in the determination of three color components: $\left(\mathrm{L}^{*}\right)$ luminosity, which varies from 0 (black) to 100 (white), $\left(\mathrm{a}^{*}\right)$, ranging from green (negative) to red (positive), $\left(b^{*}\right)$, ranging from blue (negative) to yellow (positive). The observer angle employed was $10^{\circ}$, the illuminant D65 and the equipment were calibrated using color standards supplied by the manufacturer (MACDOUGALL, 2000).

\section{Volume analysis}

Specific volume was calculated by the relation between the apparent volume of baked muffins and its weight. Three muffins were weighted on semi-analytical balance (Mettler Toledo and model PB 8001-S) and their average calculated to determine this parameter. Furthermore, the apparent volume was obtained by the millet seed displacement method (Method 10-05, AACC, 2000).

\section{Texture analysis}

Texture profile was determined using a Texturometer (CT3, Brookfield, Middleboro, MA, USA). Samples were cut into $2.5 \mathrm{~cm}$ cubes and submitted to the double compression test. The test was performed at a height of $1.25 \mathrm{~cm}$ (50\% compression) using a cylindrical acrylic probe, of $50.8 \mathrm{~mm}$ diameter, at a speed of $1 \mathrm{~mm} \mathrm{~s}^{-1}$ and range of $5 \mathrm{~s}$ between the two cycles. Parameters obtained were: hardness, elasticity and resilience (MARTÍNEZCERVERA et al., 2014).

\section{Flour's mixture particle size}

The granulometric distribution of the mixed flours were determined using the Rotachoc Chopin equipment and a set of five rounded sieves, with openings of 30, 40, 60 and 100 mesh (Method 965-22, AOAC, 2011).

\section{Sensory analysis}

In all sessions, where the sensory analysis was performed, each judge received $30 \mathrm{~g}$ of muffin, mineral water at room temperature for cleaning the papillae, and a sheet to signal the perceived sensation. Samples were served 24 hours after preparation, in a monadic sequential presentation scheme, using the balanced complete blocks design for all judges. The rank numbers received by each experiment were summed. The experiments that presented the lowest sums were chosen to evaluate in the acceptance test (MEILGAARD et al., 2007). The judges were asked to order the muffin experiments according to their flavor preference, the most preferred receiving the score 1 , following, score 2, and so on. This test was performed in two sessions for all 7 experiments (MEILGAARD et al., 2007). The evaluation sheet was in accordance to ISO 8587 (2006). The experiments that presented the lowest total sum were evaluated for acceptance test by at least 60 consumers, randomly selected, and should be habitual consumers of baked goods (IAL, 2008; ANZALDÚA-MORALES, 1994; TEIXEIRA, 2009). A structured hedonic scale of nine points was used, varying from "extremely liked" (9) to "extremely disliked” (1), as described by ISO 11136 (2013).

\section{Raw material and muffin physico-chemical characterization}

Physico-chemical characterization was carried out on the muffins with higher sensorial acceptance. Moisture, protein, lipids, ashes and dietary fiber were determined through protocols 925.10, 960.52, 920.39C, 923.03, 962.0E, respectively from AOAC (2011). Carbohydrates were determined by difference (FAO, 2002).

\section{Amino acids profile}

Amino acids were determined by reversedphase liquid chromatography (RP-HPLC) using the HPLC system (Thermo Fisher Scienctific Inc, MA USA) coupled to a UV detector at $254 \mathrm{~nm}$ (UV SPECTRA SYSTEM UV 2000) and using LUNA C18 column, $100 \AA, 5 \mu, 250 \times 4.6 \mathrm{~mm}$. Amino acid quantification was performed according to the method described by WHITE et al. (1986) and HAGEN et al. (1989).

\section{Statistical analysis}

Physico-chemical, color, texture and volume analysis were performed in triplicate.

Ciência Rural, v.52, n.7, 2022. 
The results were evaluated by univariate analysis (ANOVA) and Tukey's tests on software Statistica 10.0 (StatSoft, Inc., Tulsa, OK, USA).

The results obtained in physical analysis (volume, texture and color) of the sampled muffins were submitted to an analysis of variance (ANOVA). The following linear multiple regression was used based on the response surface methodology (RSM) to generate mathematical equations, which may explain the effects of each flour on the responses of their characterization. The amount of each of flour was expressed as pseudo-components (Table 1). Eq (1) shows the generalized model of equation used to model the experimental data:

$Y=\beta_{1} X_{1}+\beta_{2} X_{2}+\beta_{3} X_{3}+\beta_{12} X_{1} X_{2}+\beta_{13} X_{1} X_{3}+\beta_{23} X_{2} X_{3}+$ $\beta_{123} X_{1} X_{2} X_{3}$ (1)

Where $\mathrm{Y}$ is the response studied, $\beta 1$, $\beta 2, \beta 3, \beta 12, \beta 13, \beta 23$ and $\beta 123$ are the regression coefficients and $X 1, X 2$ and $X 3$ are the independent variables (flour types).

The model was evaluated by the regression coefficient $\left(\mathrm{R}^{2}\right)$ and the adjusted coefficient of determination $\left(\mathrm{R}_{\mathrm{aj}}^{2}\right)$. Triangular graphs were used to demonstrate the results for each dependent variable, based on the adjusted models by Statistica 10.0 software (STATSOFT, 2010).

\section{RESULTS AND DISCUSSION}

\section{Color}

From the experimental color data, it was obtained mathematical regression models to express the relation between the pseudo-components and the chromaticity coordinates.

$\mathrm{L}^{*}, \mathrm{a}^{*}$ and $\mathrm{b}^{*}$ of muffin's crusts (Figure 1) and crumb (Figure 2). Thus, the regression model, lack-of-fit (p), the level of significance (p), the coefficient of determination $\left(\mathrm{R}^{2}\right)$ and adjusted determination coefficient $\left(\mathrm{R}^{2}{ }_{\mathrm{aj}}\right)$ for $\mathrm{L}^{*}, \mathrm{a}^{*}$ and $\mathrm{b}^{*}$ of crusts and crumbs were set out in table 2 . Only the lightness model for crusts $\left(\mathrm{L}^{*}\right)$ and chroma a * was significant $(\mathrm{P}<0.05)$ and didn't show lack-of-fit $(\mathrm{p}$ $>0.05)$. For crust lightness $\left(\mathrm{L}^{*}\right)$ only the effect of the interaction between WF and PF was not significant. Regarding the chroma $\mathrm{a}^{*}$ of crumb all effects were significant, expect for the interaction between $\mathrm{PF}$ and WWF. The data contained in table 3 and table 4 were modeled using the RSM methodology and are presented in table 2 .

As expected, the lightness values $\left(\mathrm{L}^{*}\right)$ was higher in the crumb. The same tendency was observed in the crust and crumbs of breads prepared with pea flour (MILLAR et al., 2019b). From the contour lines

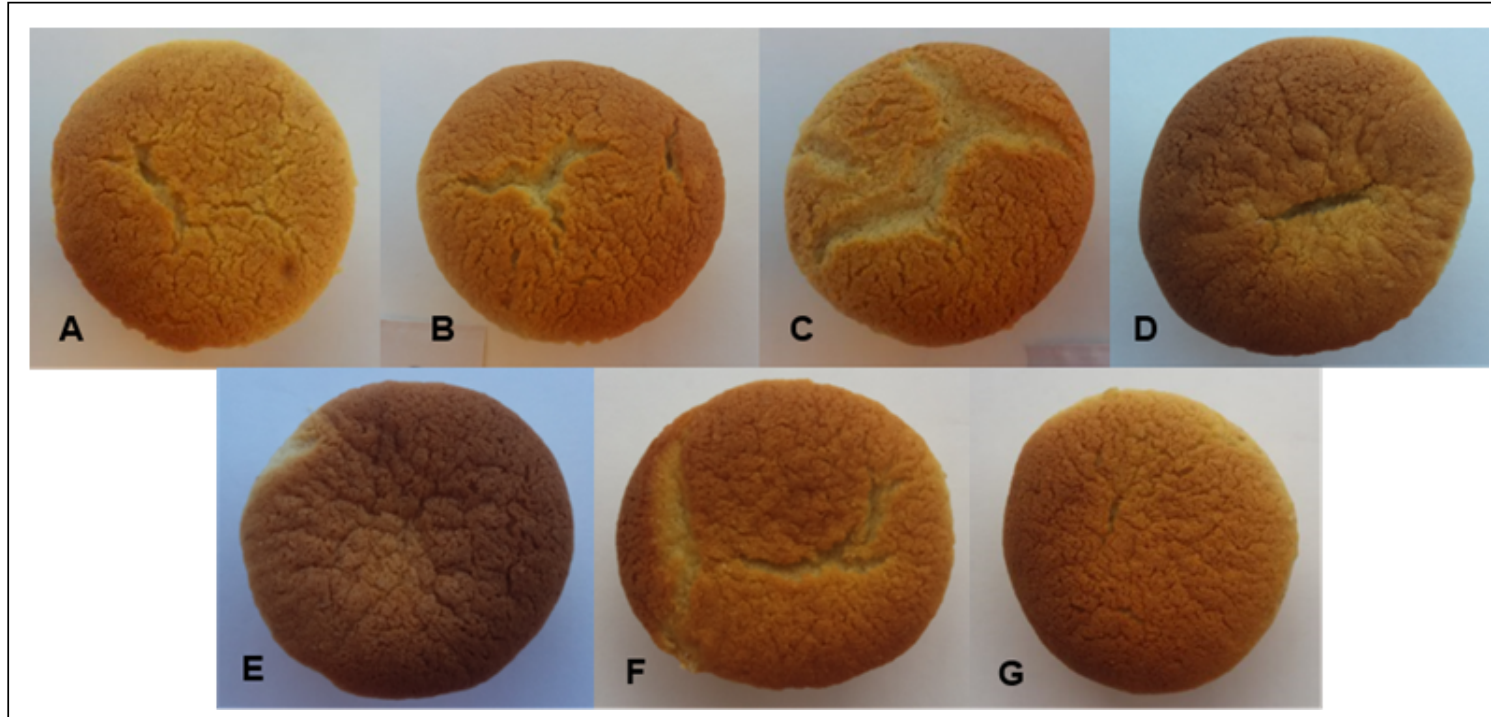

Figure 1 - Muffins' crusts prepared in each experiment. (a): $80 \%$ of WF; $10 \%$ of PF and $10 \%$ of WWF; (b): $60 \%$ of WF; $30 \%$ de PF and $10 \%$ of WWF; (c): $60 \%$ of WF; $10 \%$ of PF and $30 \%$ of WWF; (d): $70 \%$ of WF; $20 \%$ of PF and $10 \%$ of WWF; (e): $70 \%$ of WF; $10 \%$ of PF and $20 \%$ of WWF; (f): $60 \%$ of WF; $20 \%$ of PF and $20 \%$ of WWF; (g): $66 \%$ of WF; 17 $\%$ of PF and $17 \%$ of WWF; (h): $66 \%$ of WF; $17 \%$ of PF and $17 \%$ of WWF; (i): $66 \%$ of WF; $17 \%$ of PF and $17 \%$ of WWF. WF: Wheat Flour; PF: Pea Flour; WWF: Whole Wheat Flour. 


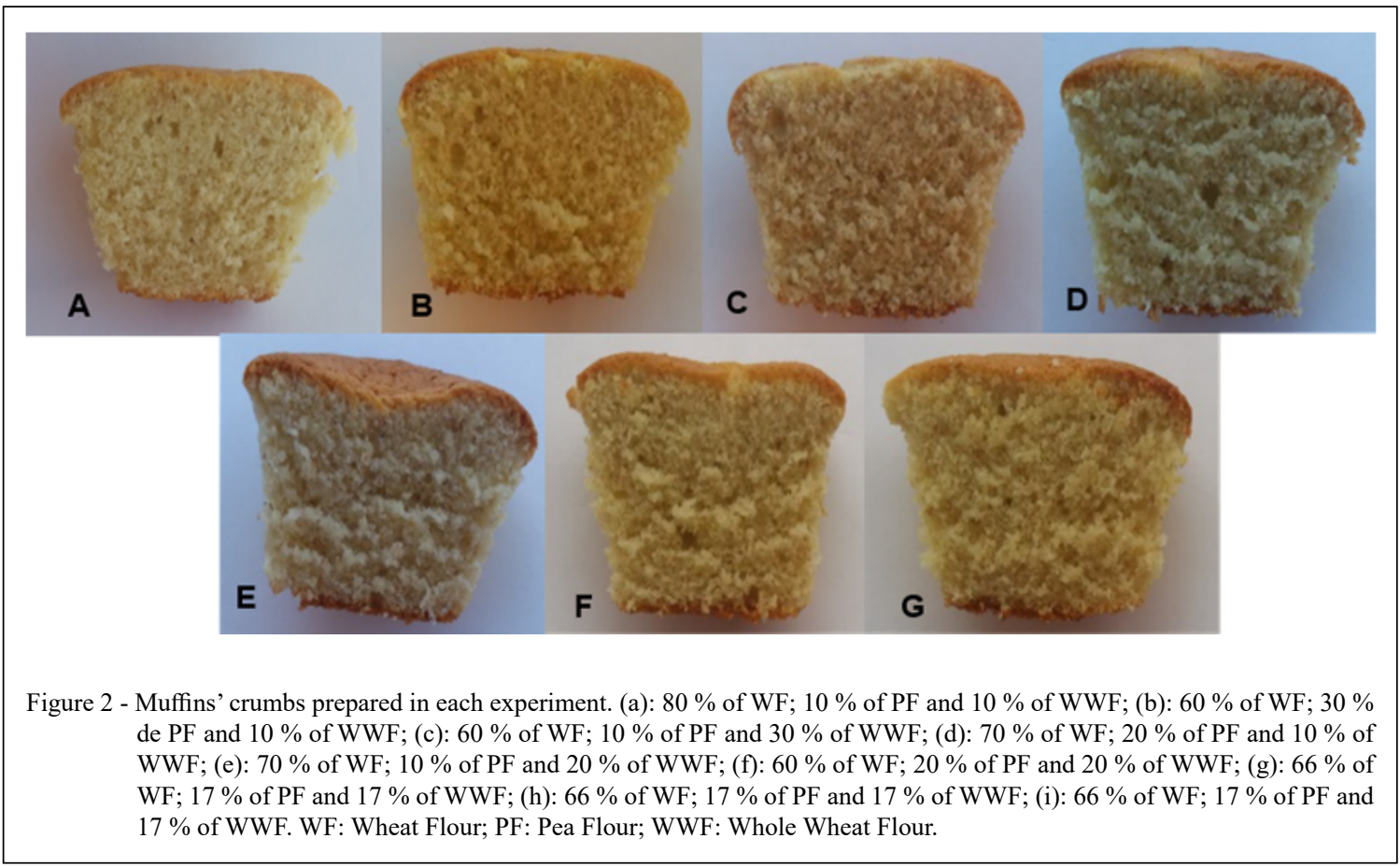

graphs (Figure 3A), it was observed higher $\mathrm{L}^{*}$ values for the crust in the WF and WWF interaction. In the other hand, lower $\mathrm{L}^{*}$ values were related to higher amounts of WWF. The crust color develops under high temperatures, during the cooking period, where the caramelization of the sugars in the flours (WF, $\mathrm{PF}, \mathrm{WWF}$ ) favors these reactions (such as Maillard's reaction) (SHEVKANI \& SINGH, 2014).

Table 2 - Regression coefficients obtained by the response surface methodology to model the effects of WF, WWF and PF on physical properties of muffins.

\begin{tabular}{|c|c|c|c|}
\hline Properties & Regression coefficient & Standard error & P value \\
\hline \multicolumn{4}{|c|}{ 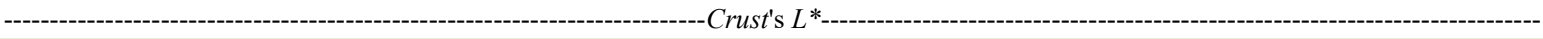 } \\
\hline (A) WF & 47.8644 & 0.43730 & $<0.001$ \\
\hline (B) $\mathrm{PF}$ & 47.2444 & 0.43730 & $<0.001$ \\
\hline (C) WWF & 44.1533 & 0.47903 & $<0.001$ \\
\hline $\mathrm{AC}$ & 19.3911 & 2.31395 & $<0.001$ \\
\hline $\mathrm{BC}$ & 10.5911 & 2.31395 & $<0.001$ \\
\hline $\mathrm{ABC}$ & -41.3166 & 11.23722 & 0.001 \\
\hline $\mathrm{R}^{2}$ & 0.8319 & & \\
\hline $\mathrm{R}^{2}$ (adjusted) & 0.7919 & & \\
\hline$P$ value (model) & $<0.001$ & $P$ value (lack of fit) & 0.6486 \\
\hline \multicolumn{4}{|c|}{ - } \\
\hline (A) $\mathrm{WF}$ & 1.91667 & 0.084543 & $<0.001$ \\
\hline (B) $\mathrm{PF}$ & 0.42111 & 0.077176 & $<0.001$ \\
\hline (C) WWF & 3.16111 & 0.077176 & $<0.001$ \\
\hline $\mathrm{AB}$ & -1.22222 & 0.408379 & 0.006934 \\
\hline $\mathrm{AC}$ & 1.05778 & 0.408379 & 0.017079 \\
\hline $\mathrm{ABC}$ & 12.09917 & 1.994331 & $<0.001$ \\
\hline $\mathrm{R}^{2}$ & 0.9757 & & \\
\hline $\mathrm{R}^{2}$ (adjusted) & 0.9699 & & \\
\hline$P$ value (model) & $<0.001$ & $\mathrm{P}$ value (lack of it) & 0.827959 \\
\hline
\end{tabular}

Note: WF: Wheat Flour; PF: Pea Flour; WWF: Whole Wheat Flour. 
Table 3 - Muffin's crust chromaticity coordinates $\mathrm{L}^{*}, \mathrm{a}^{*}$, and $\mathrm{b}^{*}$.

\begin{tabular}{|c|c|c|c|}
\hline \multirow[t]{2}{*}{ Experiment } & \multicolumn{3}{|c|}{ 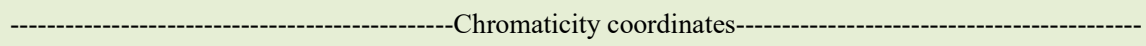 } \\
\hline & $\mathrm{L}^{*}$ & $\mathrm{a}^{*}$ & $b^{*}$ \\
\hline (a) & $47.96 \pm 0.46^{\mathrm{b}}$ & $19.81 \pm 0.11^{\mathrm{ab}}$ & $37.61 \pm 2.08^{\mathrm{bcd}}$ \\
\hline (b) & $47.34 \pm 1.89^{\mathrm{b}}$ & $19.25 \pm 0.07^{b}$ & $34.95 \pm 0.66^{\mathrm{de}}$ \\
\hline (c) & $44.15 \pm 0.76^{\mathrm{c}}$ & $19.66 \pm 0.15^{\mathrm{ab}}$ & $34.34 \pm 0.48^{\mathrm{e}}$ \\
\hline (d) & $47.37 \pm 0.45^{\mathrm{b}}$ & $19.36 \pm 0.20^{\mathrm{b}}$ & $41.06 \pm 0.99^{\mathrm{a}}$ \\
\hline (e) & $50.86 \pm 0.67^{\mathrm{a}}$ & $18.95 \pm 0.66^{\mathrm{b}}$ & $40.77 \pm 0.28^{\mathrm{ab}}$ \\
\hline (f) & $48.35 \pm 0.32^{\mathrm{b}}$ & $19.51 \pm 0.22^{\mathrm{ab}}$ & $37.83 \pm 0.55^{\text {bcd }}$ \\
\hline (g) & $48.67 \pm 0.98^{\mathrm{ab}}$ & $19.77 \pm 0.19^{\mathrm{ab}}$ & $37.55 \pm 1.37^{\text {cde }}$ \\
\hline (h) & $48.44 \pm 0.22^{\mathrm{b}}$ & $20.38 \pm 0.36^{\mathrm{a}}$ & $39.50 \pm 0.43^{\mathrm{abc}}$ \\
\hline (i) & $47.59 \pm 0.19^{b}$ & $19.81 \pm 0.41^{\mathrm{ab}}$ & $40.33 \pm 1.72^{\mathrm{abc}}$ \\
\hline${ }^{* *} \mathrm{P}$ value (ANOVA) & $<0.001$ & $<0.001$ & $<0.001$ \\
\hline
\end{tabular}

Note: (a): $80 \%$ of WF; $10 \%$ of PF and $10 \%$ of WWF; (b): $60 \%$ of WF; $30 \%$ de PF and $10 \%$ of WWF; (c): $60 \%$ of WF; $10 \%$ of PF and $30 \%$ of WWF; (d): $70 \%$ of WF; $20 \%$ of PF and $10 \%$ of WWF; (e): $70 \%$ of WF; $10 \%$ of PF and $20 \%$ of WWF; (f): $60 \%$ of WF; $20 \%$ of PF and $20 \%$ of WWF; (g): $66 \%$ of WF; $17 \%$ of PF and $17 \%$ of WWF; (h): $66 \%$ of WF; $17 \%$ of PF and $17 \%$ of WWF; (i): $66 \%$ of WF; $17 \%$ of PF and $17 \%$ of WWF.

WF: Wheat Flour; PF: Pea Flour; WWF: Whole Wheat Flour.

${ }^{* *} \mathrm{P}$ value (ANOVA): Values obtained through analysis of variance.

From the curve graph (Figure 3B) it can be seen that the chroma $\mathrm{a}^{*}$ increases as the proportion of WWF increases, and decreases when increasing the proportion of PF. This was expected since higher values of this parameter indicates a greater presence of green components.

The crumbs lightness $\left(\mathrm{L}^{*}\right)$, crust's chroma $a^{*}$ and chroma $b^{*}$ of both, crust and crumb did not generate models, but a significant difference was observed between some samples of muffins, as can be seen in tables 2 and 3 .

The crust's chroma a* was significantly higher in the interaction between the three flours (66\% WF, 17\% PF and 17\% WWF), however, it was significantly lower in the experiments (b) $(60 \%$ of WF; $30 \%$ of PF and $10 \%$ of WWF), (d) (70\% of WF, $20 \%$ of PF and $10 \%$ of WWF) and (e) (70\% WF, $10 \%$ $\mathrm{PF}$ and $20 \% \mathrm{WWF}$ ). Furthermore, for crust's chroma $\mathrm{b}^{*}$ it was significantly higher in the experiment (d) (70\% WF, 20\% PF and 10\% WWF), where there was higher proportion of PF. However, it was significantly lower with the higher proportion of WWF in the experiment (c) $(60 \% \mathrm{WF}, 10 \% \mathrm{PF}$ and $30 \% \mathrm{WWF})$. For crumb's chroma $b^{*}$, the experiment (b) $(60 \% \mathrm{WF}$, $30 \% \mathrm{PF}$ and $10 \% \mathrm{WWF}$ ), with higher PF ration was significantly higher, which justifies the presence of the yellow component.

The crumb's lightness $\left(\mathrm{L}^{*}\right)$ presented significantly higher value for experiment (a) $(80 \%$
WF, 10\% PF and 10\% WWF), with higher WF ratios, as expected. Higher proportion of WF with lower level of substitution with PF and WWF should result in an increase in lightness $\left(\mathrm{L}^{*}\right)$. GONZALEZ et al. (2020) detected in pea flour values of $77.09 \pm$ 2.11 and $27.40 \pm 1.87$ for lightness and chroma $b$ *, respectively, values close to those found for muffins with $30 \%$ substitution for pea flour (lightness $\mathrm{L}^{*}$ $73.44 \pm 0.25$, chroma $\left.b^{*}-31.51 \pm 0.05\right)$.

\section{Specific volume}

Muffins were prepared with different concentrations of pea flour, according to the information proposed in table 1 . The data obtained were modeled using the RSM methodology, but did not generate a significant model, consequently, not generating a response surface. The specific volume obtained for experiments (a), (b), (d), (e), (g) was $0.37 \mathrm{~mL} \cdot \mathrm{g}^{-1}$ and for experiments (c), (f), (h), (i) was $0.36 \mathrm{~mL} \cdot \mathrm{g}^{-1}$. There was no significant difference at $5 \%$ level of significance, therefore the variation in the flour ratio did not significantly alter this characteristic.

\section{Texture analysis}

Muffins based on pea flour were obtained from different experiments. The data contained in table 5 were modeled using the RSM methodology. All texture parameters that were analyzed did not generate models, not generating a response surface. 


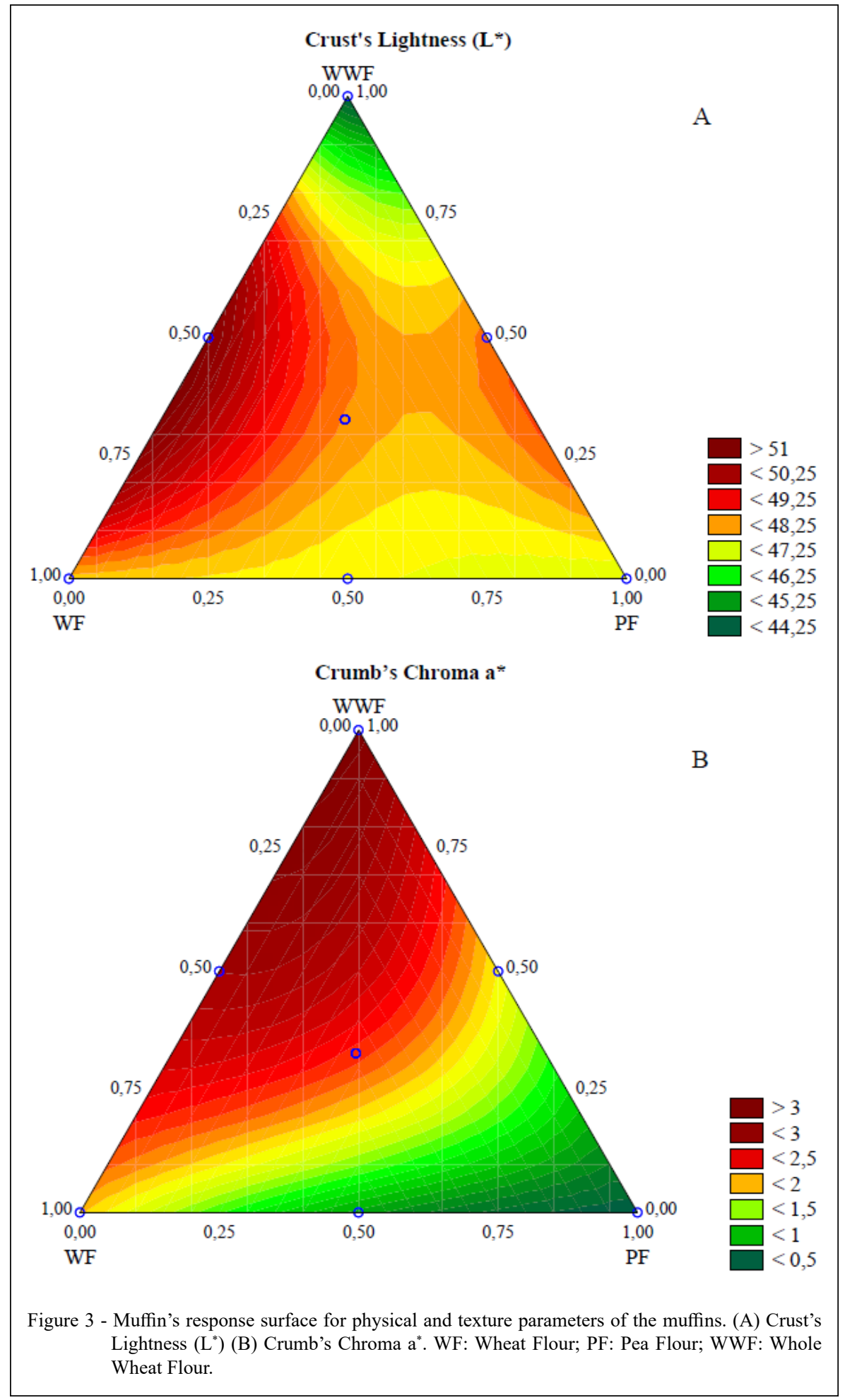

The results did not show significant differences between the muffins produced with different types of flour in terms of elasticity and resilience. GOSWAMI et al. (2015) made muffins using millet and the results of resilience agreed with those obtained in the present study.

For hardness it is possible to observe significant difference between muffin experiments 
Table 4 - Muffin's crumb chromaticity coordinates $\mathrm{L}^{*}, \mathrm{a}^{*}$, and $\mathrm{b}$ *.

\begin{tabular}{|c|c|c|c|}
\hline \multirow[t]{2}{*}{ Experiment } & \multicolumn{3}{|c|}{ - } \\
\hline & $\mathrm{L}^{*}$ & $\mathrm{a}^{*}$ & $b^{*}$ \\
\hline (a) & $76.23 \pm 0.26^{\mathrm{a}}$ & $1.92 \pm 0.14^{\mathrm{e}}$ & $29.71 \pm 0.05^{\text {bcd }}$ \\
\hline (b) & $73.44 \pm 0.25^{\mathrm{bc}}$ & $0.41 \pm 0.09^{g}$ & $31.51 \pm 0.05^{\mathrm{a}}$ \\
\hline (c) & $69.52 \pm 0.24^{\mathrm{e}}$ & $3.15 \pm 0.04^{\mathrm{a}}$ & $27.46 \pm 0.06^{\mathrm{e}}$ \\
\hline (d) & $74.91 \pm 0.18^{\mathrm{ab}}$ & $0.86 \pm 0.07^{\mathrm{f}}$ & $29.35 \pm 0.05^{\mathrm{d}}$ \\
\hline (e) & $72.86 \pm 0.72^{c}$ & $2.80 \pm 0.12^{b}$ & $27.34 \pm 0.55^{\mathrm{e}}$ \\
\hline (f) & $71.26 \pm 1.27^{\mathrm{d}}$ & $1.81 \pm 0.07^{\mathrm{e}}$ & $30.17 \pm 0.05^{\mathrm{bc}}$ \\
\hline (g) & $72.87 \pm 0.16^{\mathrm{c}}$ & $2.51 \pm 0.14^{\mathrm{c}}$ & $29.49 \pm 0.18^{d}$ \\
\hline (h) & $73.09 \pm 0.59^{\mathrm{c}}$ & $2.06 \pm 0.02^{\mathrm{de}}$ & $30.27 \pm 0.13^{b}$ \\
\hline (i) & $73.21 \pm 0.22^{\mathrm{c}}$ & $2.22 \pm 0.05^{\mathrm{d}}$ & $29.63 \pm 0.15^{\mathrm{cd}}$ \\
\hline${ }^{*} \mathrm{P}$ value (ANOVA) & $<0.001$ & $<0.001$ & $<0.001$ \\
\hline
\end{tabular}

Note: (a): $80 \%$ of WF; $10 \%$ of PF and $10 \%$ of WWF; (b): $60 \%$ of WF; $30 \%$ de PF and $10 \%$ of WWF; (c): $60 \%$ of WF; $10 \%$ of PF and $30 \%$ of WWF; (d): $70 \%$ of WF; $20 \%$ of PF and $10 \%$ of WWF; (e): $70 \%$ of WF; $10 \%$ of PF and $20 \%$ of WWF; (f): $60 \%$ of WF; $20 \%$ of PF and $20 \%$ of WWF; (g): $66 \%$ of WF; $17 \%$ of PF and $17 \%$ of WWF; (h): $66 \%$ of WF; $17 \%$ of PF and $17 \%$ of WWF; (i): $66 \%$ of WF; $17 \%$ of PF and $17 \%$ of WWF.

WF: Wheat Flour; PF: Pea Flour; WWF: Whole Wheat Flour.

P value (ANOVA): Values obtained through analysis of variance.

(Table 5). Significantly lower values were found in the interaction between the three flours $(66 \%$ of WF, $17 \%$ of PF and $17 \%$ of WWF). However, it was significantly higher in experiments (b) $(60 \%$ of
WF; $30 \%$ of PF and $10 \%$ of WWF) and (d) $(70 \%$ of WF; $20 \%$ of PF and $10 \%$ of WWF) where higher proportions of PF were used. Lower availability of water in the presence of protein can be attributed

Table 5 - Texture properties of muffins prepared with partial replacement of wheat flour with pea flour and whole wheat flour.

\begin{tabular}{lccc}
\hline Experiment & Hardness (N) & Elasticity & Resilience \\
\hline (a) & $1.90 \pm 0.16^{\mathrm{b}}$ & $0.27 \pm 0.12^{\mathrm{a}}$ & $0.19 \pm 0.02^{\mathrm{a}}$ \\
(b) & $2.63 \pm 0.23^{\mathrm{a}}$ & $0.40 \pm 0.00^{\mathrm{a}}$ & $0.17 \pm 0.00^{\mathrm{a}}$ \\
(c) & $1.94 \pm 0.15^{\mathrm{b}}$ & $0.37 \pm 0.06^{\mathrm{a}}$ & $0.18 \pm 0.01^{\mathrm{a}}$ \\
(d) & $2.63 \pm 0.22^{\mathrm{a}}$ & $0.37 \pm 0.06^{\mathrm{a}}$ & $0.18 \pm 0.00^{\mathrm{a}}$ \\
(e) & $2.20 \pm 0.09^{\mathrm{ab}}$ & $0.33 \pm 0.06^{\mathrm{a}}$ & $0.17 \pm 0.00^{\mathrm{a}}$ \\
(f) & $1.93 \pm 0.13^{\mathrm{b}}$ & $0.37 \pm 0.06^{\mathrm{a}}$ & $0.16 \pm 0.02^{\mathrm{a}}$ \\
(g) & $1.78 \pm 0.06^{\mathrm{b}}$ & $0.30 \pm 0.00^{\mathrm{a}}$ & $0.17 \pm 0.01^{\mathrm{a}}$ \\
(h) & $1.78 \pm 0.17^{\mathrm{b}}$ & $0.30 \pm 0.00^{\mathrm{a}}$ & $0.16 \pm 0.01^{\mathrm{a}}$ \\
(i) & $1.80 \pm 0.10^{\mathrm{b}}$ & $0.40 \pm 0.00^{\mathrm{a}}$ & $0.18 \pm 0.01^{\mathrm{a}}$ \\
${ }^{*}$ P value (ANOVA) & $<0.001$ & $<0.001$ \\
\hline
\end{tabular}

Note: (a): $80 \%$ of WF; $10 \%$ of PF and $10 \%$ of WWF; (b): $60 \%$ of WF; $30 \%$ de PF and $10 \%$ of WWF; (c): $60 \%$ of WF; $10 \%$ of PF and $30 \%$ of WWF; (d): $70 \%$ of WF; $20 \%$ of PF and $10 \%$ of WWF; (e): $70 \%$ of WF; $10 \%$ of PF and $20 \%$ of WWF; (f): $60 \%$ of WF; $20 \%$ of PF and $20 \%$ of WWF; (g): $66 \%$ of WF; $17 \%$ of PF and $17 \%$ of WWF; (h): $66 \%$ of WF; $17 \%$ of PF and $17 \%$ of WWF; (i): $66 \%$ of WF; $17 \%$ of PF and $17 \%$ of WWF.

WF: Wheat Flour; PF: Pea Flour; WWF: Whole Wheat Flour.

*P value (ANOVA): Values obtained through analysis of variance. 
to higher muffins' hardness values. According to PREICHARDT et al. (2011) there is a negative correlation between moisture and hardness. However, the decrease in hardness may have occurred due to the dilution of gluten by pea flour, since the development of gluten is a determinant of hardness (SCHAMNE et al., 2010).

\section{Flour's mixture particle size}

The amount of flour that was retained in the 60 mesh sieve in each mixture ranged from $3.97 \mathrm{~g}$ / $100 \mathrm{~g}$ to $9.43 \mathrm{~g} / 100 \mathrm{~g}$.

Approximately $96 \mathrm{~g} / 100 \mathrm{~g}$ of experiment (a) $(80 \% \mathrm{WF} ; 10 \% \mathrm{PF}$ and $10 \% \mathrm{WWF})$ passed through the 60 mesh sieve, thus, the maximum concentration of WF and minimum concentration of PF and WWF follows the Normative Instruction No. 8, of June 2, 2005 (BRASIL, 2005), which determines that 95 $\mathrm{g} / 100 \mathrm{~g}$ of the product must pass through a sieve with a $250 \mu \mathrm{m}$ mesh opening (60 mesh). However, with the increase of the concentration of other flours (PF and WWF) this percentage was reduced and there was an increase in particle retention in sieves with an opening smaller than 60 mesh

The granulometric characteristic of the raw material interferes with the properties of baked good. The uniformity of the flour particles impact in the quality of the final products, impacting water absorption, sensory characteristics (such as appearance, taste and texture) and mixing time. Flours with finer and uniform particles promote greater incorporation into the dough, resulting in a more cohesive dough with low extensibility (TORBICA et al., 2012; BORGES et al., 2006; GAINES, 1990). Even with some mixtures showing residuals in the 60 mesh sieve, there was no significant difference in specific volume, resilience, elasticity and only crust lightness and $\mathrm{a}^{*}$ chroma presented a response surface. Therefore, the mixture between the flours had little effect on the evaluated physical parameters.

\section{Sensory analysis}

Before conducting the ranking and acceptance tests, a questionnaire was applied to determine the consumer's profile. Both tests totaled 143 untrained judges, $62.94 \%$ were women and $37.06 \%$ were men. The predominant age group was between 18 and 25 years (42.66\%), followed by the range between 26 and 35 years $(39.86 \%), 36$ and 45 years $(6.99 \%), 46$ and 55 years $(6,29 \%)$ and over 56 years $(4.20 \%)$. Regarding education level, most of the interviewees $(37.06 \%)$ had incomplete postgraduation degrees, while the others had incomplete higher education (31.47\%), complete higher education (20.28\%), complete postgraduation (7.69\%), complete secondary level $(2.80 \%)$ and incomplete secondary level $(0.70 \%)$.

Virtually $100 \%$ of the interviewed judges $(99.30 \%)$ ingest legumes of different types, with $74.13 \%$ of them being pea consumers. The frequency of consumption of legumes presented by the judges was distributed in: once a day $(39.16 \%)$, two to five times a week $(34.97 \%)$, twice a day $(12.59 \%)$, once a week $(11.19 \%)$, once a month $(0.70 \%)$ and no consumption $(0.70 \%)$.

The ranking test was performed with 39 judges. The experiments were performed in two sessions, the experiments that demonstrated the lowest sum in relation to flavor were $(\mathrm{a}=94),(\mathrm{c}=94)$ and $(g=67)$. These experiments were submitted to the acceptance test, where 112 judges attended. BARROS et al. (2018) used the ranking and acceptance tests to evaluate muffins partially replaced by bean flour. VENTURINI et al. (2011) evaluated fresh chicken sausage formulations using a ranking and acceptance test. In the present work, the ranking test was used to order the muffin experiments. Those with the lowest score were the most preferred and therefore the ones selected to participate in the acceptance test. A large number of samples in the acceptance test could make it difficult for judges to choose the most preferred muffin experiment. According to MEILGAARD et al. (2007); AMERINE et al. (1965) and ISO 8587 (2006) ranking test can be applied as a sample pre-selection, as discriminatory criteria or hedonic preference.

The averages of scores attributed by the judges in the acceptance test are shown in table 6 . Statistical analysis showed that the muffins did not differ significantly in taste, however, they differed in relation to texture. Regarding color and overall acceptance, the experiment (a) presented significantly higher mean scores.

Although all muffins experiments were well accepted, it was observed that experiment (a) (80\% WF, 10\% WWF and 10\% PF) stood out from the others in all evaluated attributes.

\section{Physico-chemical analysis}

The muffins experiments selected for sensory acceptance analysis underwent physicochemical characterization (Table 7). The experiment (a) had significantly higher protein content in relation to other samples. Protein contents were suitted to recommended range. The experiment was chosen due to the sensory result, longing to an enhanced probability of commercialization. Authough the 
Table 6 - Average score of the sensory attributes of the acceptance test for the three selected samples $(n=112)$.

\begin{tabular}{|c|c|c|c|c|}
\hline Experiment & Color & Taste & Texture & Global acceptance \\
\hline (a) & $7.86^{\mathrm{a}}$ & $7.53^{\mathrm{a}}$ & $7.74^{\mathrm{a}}$ & $7.78^{a}$ \\
\hline (c) & $7.39^{b}$ & $7.42^{\mathrm{a}}$ & $7.48^{\mathrm{ab}}$ & $7.46^{\mathrm{b}}$ \\
\hline (g) & $7.57^{\mathrm{b}}$ & $7.25^{\mathrm{a}}$ & $7.38^{\mathrm{b}}$ & $7.38^{\mathrm{b}}$ \\
\hline
\end{tabular}

Note: (a): $80 \%$ de WF, $10 \%$ de WWF e $10 \%$ de PF.

(c): $60 \%$ of WF, $30 \%$ of WWF and $10 \%$ of PF.

(g) $66 \%$ of WF, $17 \%$ of WWF and $17 \%$ de PF.

WF: Wheat Flour; PF: Pea Flour; WWF: Whole Wheat Flour.

highter protein content explored in other experiments, their samples were not as well accepted as the samples evaluated in the present study.

Experiment (c) presented significantly higher dietary fiber content due to the higher concentration of WWF, which has a high dietary fiber content, as observed in table 7 . Humidity was significantly lower for experiment (c), because the higher concentration of WWF, significantly increased the dietary fiber content, causing greater retention of moisture in the mass. The lipid content was significantly higher for the experiment $(\mathrm{g})$, because the higher content of PF and WWF incorporated lipids to the mass.

\section{Amino acids profile analysis} shown in table 8 .

The total amino acid profile of pea flour is

Total amino acid analysis revealed that lysine $(22.91 \%)$ was the highest amino acid found, followed by leucine $(21.21 \%)$, phenylalanine
$(14.79 \%)$. The other essential amino acids presented in lower proportions. The amino acids profile of yellow peas have shown lower values for most of the amino acids, with predominance of leucine and lysine among the essential amino acids (MA et al., 2017). According to PHILIPP et al. (2017) peas contain a protein profile that include amino acids like lysine, which is often deficient in cereals. In this sense, the use of pea flour in baked goods can contribute to the improvement of the protein profile.

Essential amino acids present in pea flour, in reference to the requirements of FAO / WHO (2007) protein standard for adults (histidine, isoleucine, leucine, lysine, methionine, cysteine, phenylalanine + tyrosine, threonine, tryptophan and valine), shows a high biological quality, although the presence of tryptophan was not detected. However, the other essential amino acids were present in greater quantities than were necessary for daily consumption (Table 8). This means that the minimum use of pea flour $(10 \%)$ in muffins experiment (a) that had the

Table 7 - Physico-chemical composition of the muffins selected by the acceptance test.

\begin{tabular}{lcccc}
\hline Components & (a) $(\%)$ & (c) $(\%)$ & (g) $(\%)$ & ${ }^{*}$ P value $($ ANOVA) \\
\hline Moisture & $26.85 \pm 0.07^{\mathrm{b}}$ & $26.64 \pm 0.02^{\mathrm{c}}$ & $27.40 \pm 0,00^{\mathrm{a}}$ & $<0.001$ \\
Ashes & $1.39 \pm 0.01^{\mathrm{b}}$ & $1.60 \pm 0.00^{\mathrm{a}}$ & $1.34 \pm 0,03^{\mathrm{b}}$ & $<0.001$ \\
Protein & $8.56 \pm 0.06^{\mathrm{a}}$ & $7.54 \pm 0.00^{\mathrm{b}}$ & $7.60 \pm 0,00^{\mathrm{b}}$ & $<0.001$ \\
Lipids & $14.50 \pm 0.00^{\mathrm{b}}$ & $14.42 \pm 0.01^{\mathrm{b}}$ & $14.85 \pm 0,04^{\mathrm{a}}$ & $<0.001$ \\
Dietery Fiber & $1.89 \pm 0.01^{\mathrm{b}}$ & $2.76 \pm 0.01^{\mathrm{a}}$ & $1.65 \pm 0,01^{\mathrm{c}}$ & $<0.001$ \\
Carbohydrates & $46.82 \pm 0.12^{\mathrm{b}}$ & $47.05 \pm 0.02^{\mathrm{b}}$ & $47.83 \pm 0,08^{\mathrm{a}}$ & $<0.001$ \\
\hline
\end{tabular}

Note: (a): $80 \%$ of WF, $10 \%$ of WWF and $10 \%$ of PF.

(c): $60 \%$ of WF, $30 \%$ of WWF and $10 \%$ of PF.

(g): $66 \%$ of WF, $17 \%$ of WWF and $17 \%$ of PF.

WF: Wheat Flour; PF: Pea Flour; WWF: Whole Wheat Flour.

${ }^{*} \mathrm{P}$ value (ANOVA): Values obtained through analysis of variance. 
Table 8 - Essencial amino acids composition in pea flour (PF).

\begin{tabular}{lcc}
\hline Amino acids & Amino acids (mg/100g of sample & FAO/WHO (2007) (mg/100g of sample) \\
\hline Histidine & 380 & 15 \\
Isoleucine & 1080 & 30 \\
Leucine & 1750 & 59 \\
Lysine & 1890 & 45 \\
Methionine & 110 & 16 \\
Cysteine & 80 & 6 \\
Phenylalanine & 1220 & $38 *$ \\
Tyrosine & 690 & \\
Threonine & 760 & 23 \\
Tryptophan & - & 6 \\
Valine & 1020 & 39 \\
$\sum$ Essential Amino Acids & 8250 & 277 \\
\hline
\end{tabular}

Note: FAO/WHO. Food and Agriculture Organization and World Health Organization (2007) protein and amino acid requirements in human nutrition: report of a joint FAO/WHO/UNU expert consultation. WHO Technical Report series 935, Geneve.

${ }^{*}$ Phenylalanine + Tyrosine.

best accepted sensory provides more than the amount of daily consumption needed in virtually all essential amino acids. With 5 muffins (1.66 g of PF in each muffin) it is possible to meet the daily requirement of essential amino acids in relation to the PF ingested. More studies would be needed to consider the essential amino acids present in WF and WWF. Therefore, the incorporation of pea flour in the muffin's formulation can be a good alternative to increase the nutritional value of the product developed.

\section{CONCLUSION}

Using mixture design methodologies has reduced the number of experiments carried out to identify a muffin with suitable characteristics.

From the physical and texture analysis it was observed that the crust's hardness and lightness $\left(L^{*}\right)$ generated regression models with the interaction of the flours. The interaction between WF and WWF produced muffins with brighter crusts. Higher hardness was found in muffins with higher PF ratio.

The experiment (a) with $80 \% \mathrm{WF}+10 \%$ $\mathrm{WWF}+10 \% \mathrm{PF}$ was selected by the acceptance test due to higher scores attributed by the judges. The use of pea flour can be a good alternative for product enrichment since the minimum use of 5 muffins (1.66 $\mathrm{g}$ of PF each muffin) is enough for the $\mathrm{PF}$ ingested to meet the daily requirement essential amino acids.

\section{DECLARATION OF CONFLICT OF INTEREST}

The authors declare no conflict of interest. The founding sponsors had no role in the design of the study; in the collection, analyses, or interpretation of data; in the writing of the manuscript, and in the decision to publish the results.

\section{BIOETHICS AND BIOSSECURITY COMMITTEE APPROVAL}

The study was carried out with the approval of the Research Ethics Committee of the Health Sector / UFPR, under the consubstantiated opinion $\mathrm{n}^{\circ} 1755406$.

\section{ACKNOWLEDGEMENTS}

The authors gratefully acknowledge Coordenação de Aperfeiçoamento de Pessoal de Nível Superior (CAPES)-Brazil for the financial resources provided, Empresa Brasileira de Pesquisa Agropecuária (EMBRAPA-Hortaliças.

\section{AUTHORS' CONTRIBUTIONS}

D. S. Gomes performed the analysis in the laboratory. The authors contribued equally in the writting of de manuscript.

\section{REFERENCES}

AACC. Approved Methods of the American Association of Cereal Chemists. 10. ed. St. Paul: American Association of Cereal Chemists, 2000.

Ciência Rural, v.52, n.7, 2022. 
AMERINE, M. A. et al. Principles of sensory evaluation of food. New York: Academic Press, 1965. 612p.

ANZALDÚA-MORALES,A.Laevaluaciónsensorialdelosalimentos en la teoría y la prática. Zaragoza: Acribia SA, 1994. 214 p.

AOAC - Association of official analytical chemists. Official methods of analysis. 18. ed. Gaithersburg: Association of Official Analytical Chemists, 2005. Review 2011.

BECK, S. M. et al. Low moisture extrusion of pea protein and pea fibre fortified rice starch blends. Journal of Food Engineering, v.231, p.61-71, aug. 2018. Available from: < https://doi org/10.1016/j.jfoodeng.2018.03.004>. Accessed: Jul. 07, 2020. doi: 10.1016/j.jfoodeng.2018.03.004

BARROS, L. F. T. et al. Different classes of bean flour added to muffins. Brazilian Journal of Food Technology, v.21, p.e2017081, aug. 2018. Available from: <https://www.scielo.br/scielo. php?script $=$ sci_arttext\&pid=S1981-67232018000100455\&lng=en \&nrm $=\mathrm{iso} \& \mathrm{t} \operatorname{lng}=\mathrm{pt}>$. Accessed: Dec. 15,2020 . doi: 10.1590/19816723.08117.

BORGES, J. T. S. et al. Utilização de farinha mista de aveia e trigo na elaboração de bolos. Boletim de Centro de Pesquisa de Processamento de Alimentos, v.24, n.1, p.145-162, jan./jun. 2006. Available from: $<$ https://revistas.ufpr.br/alimentos/article/view/5286/3957>. Accessed: Dec. 15, 2020. doi: 10.5380/cep.v24i1.5286.

BOX, G. E. P. et al. Statistics for experimenters: Design, innovation and discovery. 2. ed. New York: Wiley, 2005. 672 p.

BRASIL. Instrução Normativa n.8, de 2 de junho de 2005 . Regulamento técnico de identidade e qualidade da farinha de trigo. Seção 1. 2005. Available from: <https://www.gov.br/agricultura/ptbr/assuntos/inspecao/produtos-vegetal/legislacao-1/normativoscgqv/pocs/instrucao-normativa-no-8-de-02-de-junho-de-2005farinha-de-trigo/view>. Accessed: Dec. 16, 2020.

CARMO, C. S. et al. The impact of extrusion parameters on physicochemical, nutritional and sensorial properties of expanded snacks from pea and oat fractions. LWT - Food Science and Technology, v.112, p.108252, sep. 2019. Available from: <https:// www.sciencedirect.com/science/article/pii/S0023643819305882>. Accessed: Dec. 13, 2020. doi: 10.1016/j.lwt.2019.108252.

COLLAR, C. et al. Impact of ancient cereals, pseudocereals and legumes on starch hydrolysis and antiradical activity of technologically viable blended breads. Carbohydrate Polymers, v.113, p.149-158, nov.2014. Available from: <https://doi org/10.1016/j.carbpol.2014.07.020>. Accessed: Apr. 26, 2020. doi: 10.1016/j.carbpol.2014.07.020

FAO - Food and Agriculture Organization of the United Nations. Food energy - methods of analysis and conversion factors. In:_ Summary: integration of analytical methods and food energy conversion fator. FAO food and nutrition paper 77. Rome: FAO, 2002. Cap. 4, p. 57-60.

FAO - Food and Agriculture Organization of the United Nations. Production 2018. Available from: $<$ http://www.fao.org/ faostat/en/\#data/QC>. Accessed: Jul. 03, 2020.

FAO/WHO. Protein and amino acid requirements in human nutrition: report of a joint $\mathrm{FAO} / \mathrm{WHO} / \mathrm{UNU}$ expert consultation. In: Food and Agriculture Organization and World Health
Organization WHO Technical Report Series, Geneva, 2007. Available from: <https://apps.who.int/iris/bitstream/ handle/10665/43411/WHO? sequence=1>. Accessed: Jul. 03, 2020.

GAINES, C. S. Influence oh Chemical and Physical Modification of Soft Wheat Protein on Sugar-Snap Cookie Dough Consistency, Cookie Size, and Hardness. Cereal Chemistry, v.67, n.1, p.73-77, 1990. Available from: <https://pascal-francis.inist.fr/vibad/index.php?a ction=getRecordDetail\&idt=6889946>. Accessed: Dec. 15, 2020

GONZALEZ, M. et al. Effect ofthe drying temperature on color, antioxidant activity and in vitro digestibility of green pea (Pisum sativum L.) flour. Starch, v.72, p.1-7, feb. 2020. Available from: $<$ https://onlinelibrary.wiley.com/doi/full/10.1002/ star.201900228>. Accessed: Dec. 16, 2020. doi: 10.1002/ star.201900228.

GOSWAMI, D. et al. Barnyard millet based muffins: Physical, textural and sensory properties. LWT - Food Science and Technology, v.64, n.1, p.374-380, nov. 2015. Available from: $<$ https://doi.org/10.1016/j.lwt.2015.05.060>. Accessed: Apr. 27, 2020. doi: 10.1016/j.lwt.2015.05.060.

HAGEN, S. et al. Precolumn phenylisothiocyanate derivatization and liquid chromatography of amino acids in food. Journal Association of Official Analytical Chemists, v.72, n.6, p.912-916, nov. 1989. Available from: <https://doi.org/10.1093/jaoac/72.6.912>. Accessed: Jul. 9, 2020. doi: 10.1093/jaoac/72.6.912.

IAL - Instituto Adolfo Lutz. Métodos químicos e físicos para análise de alimentos. 4. ed. São Paulo: Instituto Adolfo Lutz, 2008, 1020 p.

ISO, 8587. Sensory analysis - Methodology - Ranking. Geneva: Switzerland: International Organization for Standarization, 2006.

ISO, 11136. Sensory analysis - Methodology - Guidelines for conductiong hedonic tests with consumers in a controlled área. Geneva: Switzerland: International Organization for Standarization, 2013.

IKEDA et al. Influence of Brazilian pine seed flour addition on rheological, chemical and sensory properties of gluten-free rice flour cakes. Ciência Rural, v.48, n.6, e20170732., 2018. Available from: <https://doi.org/10.1590/0103-8478cr20170732>. Accessed: Apr. 30, 2020. doi: 10.1590/0103-8478cr20170732.

JAUHARAH, M. Z. A. et al. Physicochemical and sensorial evaluation of biscuit and muffin incorporated with young corn powder. Sains Malaysiana, v.43, n.1, p.45-52, 2014. Available from: $<$ https://core.ac.uk/download/pdf/19203484.pdf $>$. Accessed: Apr. 25, 2020.

KEHLET, U. et al. Meatballs with 3\% and 6\% dietary fibre from rye bran or pea fibre - Effects on sensory quality and subjective appetite sensations. Meat Science, v.125, p.66-75, mar. 2017. Available from: <https://www.sciencedirect.com/science/ article/pii/S0309174016303321>. Accessed: Dec. 13, 2020. doi: 10.1016/j.meatsci.2016.11.007.

MA, Z. et al. In vitro digestibility, protein composition and technofunctional properties of Saskatchewan grown yellow field peas (Pisum sativum L.) as affected by processing. Food Research International, v.92, p.64-78, feb. 2017. Available from: <https:// doi.org/10.1016/j.foodres.2016.12.012>. Accessed: Apr. 25, 2020. doi: 10.1016/j.foodres.2016.12.012. 
MACDOUGALL, D. B. Colour in Food, improving quality. Boca Raton: CRC Press, 2000.

MARTÍNEZ-CERVERA, S. et al. Comparison of different polyols as total sucrose replacers in muffins: Thermal, rheological, texture and tability properties. Food Hydrocolloids, v.35, p.1-8, mar. 2014. Available from: $<$ https://doi.org/10.1016/j. foodhyd.2013.07.016>. Accessed: Apr. 15, 2020. doi: 10.1016/j. foodhyd.2013.07.016.

MEILGAARD, M. et al. Sensory evaluation techniques. Boca Raton: Taylor \& Francis, 2007.

MILLAR, K. A. et al. Proximate composition and anti-nutritional factors of fava-bean (Vicia faba), green-pea and yellow-pea (Pisum sativum) flour. Journal of Food Composition and Analysis, v.82, p.103233, sep. 2019a. Available from: $<$ https://www.sciencedirect. com/science/article/pii/S0889157518304988>. Accessed: Dec. 13, 2020. doi: $10.1016 /$ j.jfca.2019.103233.

MILLAR, K. A. et al. Dough properties and baking characteristics of white bread, as affected by addition of raw, germinated and toasted pea flour. Innovative Food Science and Emerging Technologies, v.56, p.102189, aug. 2019b. Available from: $\quad<$ https://www.sciencedirect.com/science/article/pii/ S1466856418311871>. Accessed: Dec. 13, 2020. doi: 10.1016/j. ifset.2019.102189.

LU, Z. H. et al. Effect of roasted pea flour/starch and encapsulated pea starch incorporation on the in vitro starch digestibility of pea breads. Food Chemistry, v.245, p.71-78, apr. 2018. Available from: $\quad<$ https://www.sciencedirect.com/science/article/pii/ S0308814617316758>. Accessed: Dec. 13, 2020. doi: 10.1016/j. foodchem.2017.10.037.

PHILIPP, C. etal. Instrumental and sensory properties of pea proteinfortified extruded rice snacks. Food Research International, v.102, p.658-665, may 2017. Available from: <https://www. sciencedirect.com/science/article/pii/S0963996917306130>. Accessed: Dec. 15, 2020. doi: 10.1016/j.foodres.2017.09.048.

PIETRASIK, Z. et al. Utilization of pea starch and fibre fractions for replacement of wheat crumb in beef burgers. Meat Science, v.161, p.107974, mar. 2020. Available from: <https://www.sciencedirect. com/science/article/pii/S0309174019306503>. Accessed: Dec. 13, 2020. doi: h10.1016/j.meatsci.2019.107974.

PREICHARDT, L. D. et al. The role of xanthan gum in the quality of gluten free cakes: improved bakery products for coeliac patients. International Journal of Food Science and Technology, v.46, p.2591-2597, 2011. Available from: <https://doi.org/10.1111 /j.1365-2621.2011.02788.x>. Accessed: Apr. 27, 2020. doi: 10.1111/j.1365-2621.2011.02788.x

REN, Y. et al. Functionality and starch digestibility of wrinkled and round pea flours of two different particle sises. Food Chemistry, v.336, p.127711, jan. 2021. Available from: <https://www.sciencedirect.com/science/article/pii/ S0308814620315739>. Accessed: Dec. 13, 2020. doi: 10.1016/j. foodchem.2020.127711.

SCHAMNE, C. et al. Obtention and characterization of glutenfree baked products. Food Science and Technology, v.30, n.3, p.741-750, jul./set. 2010. Available from: $<$ https://doi.org/10.1590/ S0101-20612010000300027>. Accessed: Apr. 27, 2020. doi: 10.1590/S0101-20612010000300027.
SCIAMMARO, L. P. et al. Gluten-free baked muffins developed with Prosopis alba flour. LWT - Food Science and Technology, v.98, p.568-576, dec. 2018. Available from: <https://www. sciencedirect.com/science/article/pii/S0023643818307771>. Accessed: Dec. 13, 2020. doi: 10.1016/j.lwt.2018.09.045.

SHEVKANI, K.; SINGH, N. Influence of kidney bean, field pea and amaranth protein isolates on the characteristics of starch-based gluten-free muffins. International Journal of Food Science and Technology, v.49, n.10, p.2237-2244, mar. 2014. Available from: $<$ https://doi.org/10.1111/ijfs.12537>. Accessed: Apr. 26, 2020. doi: 10.1111/ijfs. 12537 .

SILVA, A. A. et al. Green banana flour as a functional ingredient in food products. Ciência Rural, v. 45, n. 12, p. 2252-2258, dez. 2015. Available from: <https://doi.org/10.1590/01038478cr20140332>. Accessed: Apr. 30, 2020. doi: 10.1590/0103$8478 \mathrm{cr} 20140332$.

STRUCK, S. et al. Fiber enriched reduced sugar muffins made from iso-viscous batters. Food Science and Technology, v.65, p.32-38, jan. 2016. Available from: <https://doi.org/10.1016/j. lwt.2015.07.053>. Accessed: Apr. 25, 2020. doi: 10.1016/j. lwt.2015.07.053.

TEIXEIRA, L. V. Sensory analysis in the food industry. Revista do Instituto de Laticínios Cândido Tostes, v.64, n.366, p.12-21, jan./ feb. 2009. Available from: <https://www.revistadoilct.com.br/rilct/ article/view/70/76>. Accessed: Apr. 26, 2020.

TORBICA, A. et al. Rice and buckwheat flour characterisation and its relation to cookie quality. Food Research International, v.48, n.1, p.277-283, aug. 2012. Available from: <https://www. sciencedirect.com/science/article/pii/S0963996912001354>. Accessed: Dec. 15, 2020. doi: 10.1016/j.foodres.2012.05.001.

VENTURINI, A. C. et al. Sensory and microbiological evaluation of uncured fresh chicken sausage with reduced fat content. Food Science and Technology, v.31, n.3, p.629-634, jul./ sep. 2011. Available from: $<$ https://www.scielo.br/scielo.php?script=sci_artt ext\&pid=S0101-20612011000300012>. Accessed: Dec. 15, 2020. doi: 10.1590/S0101-20612011000300012.

VATANSEVER, S. et al. Physicochemical and multi-scale structural alterations of pea starch induced by supercritical carbon dioxide + ethanol extraction. Food Chemistry, p.128699, nov. 2020. Available from: <https://www.sciencedirect.com/science/ article/pii/S0308814620325619>. Accessed: Dec. 13, 2020. doi: 10.1016/j.foodchem.2020.128699

WHITE, J. A., et al. An evaluation of the waters pico-tag system for the amino-acid-analysis of food materials. Journal of Automatic Chemistry, v.8, n.4, p.170-177, oct./dec. 1986. Available from: <https://www.ncbi.nlm.nih.gov/pmc/ articles/PMC2547673/>. Accessed: Apr. 26, 2020. doi: 10.1155/ S1463924686000330.

YILDIZ, E. et al. Development of pea flour based active films produced through different homogenization methods and their effects on lipid oxidation. Food Hydrocolloids, v.111, p.106238, feb. 2021. Available from: <https://www.sciencedirect.com/ science/article/pii/S0268005X20309784>. Accessed: Dec. 13, 2020. doi: 10.1016/j.foodhyd.2020.106238.

YILMAZ, M. T. et al. A mixture design study to determine interaction effects of wheat, buckwheat, and rice flours in an 
aqueous model system. Food Science and Technology, v.61, n.2, p.583-589, may. 2015. Available from: <https://doi.org/10.1016/j. lwt.2014.11.045>. Accessed: Jul. 04, 2020. doi: 10.1016/j. lwt.2014.11.045.

ZHAO, J. et al. Production of biscuits by substitutionwith different ratios of yellow pea flour. Grain \& Oil Science and Technology, v.2, n.4, p.91-96, dec. 2019. Available from: <https://www.
sciencedirect.com/science/article/pii/S2590259819300457>. Accessed: Dec. 13, 2020. doi: 10.1016/j.gaost.2019.09.004.

ZHOU, D. et al. Structural characteristics and physicochemical properties of field pea starch modified by physical, enzymatic, and acid treatments. Food Hydrocolloids, v.93, p.386-394, aug. 2019. Available from: < https:// www.sciencedirect.com/science/article/pii/S0268005X18311421>. Accessed: Dec. 13, 2020. doi: 10.1016/j.foodhyd.2019.02.048. 